\title{
ANALISIS KUALITAS, KUATITAS DAN KINERJA (K3) PEGAWAI PADA BADAN PUSAT STATISTIK KABUPATEN KERINCI
}

\author{
M.DHANY ALSUNAH
}

\author{
STIA Nusantara Sakti Sungai Penuh \\ Email : \\ m.dhanyalsunah@gmail.com
}

\begin{abstract}
Thesis. Analysis of Quality, Quantity and Performance (K3) of Employees at the Central Statistics Agency of Kerinci Regency. The Central Bureau of Statistics is an organization that has been established based on Presidential Regulation Number 86 of 2007 concerning the Central Statistics Agency and the Regulation of the Head of the Central Statistics Agency Number 7 of 2008 concerning the Organization and Work Procedure of The Central Statistics Agency located in Kerinci Regency. The formulation of the research problem, namely, what is the Quality, Quantity and Performance (K3) of Employees at the Central Statistics Agency of Kerinci Regency? The research objective is to see the quality, quantity and performance (K3) of the employees of the Central Statistics Agency of Kerinci Regency. This research uses a qualitative approach where data is obtained through field interview guides to 7 informants who refer to the research indicators, namely 1. Knowledge. 2. Skills. 3. Capability 4. Number of Hours Worked. 5. Use of time. 6. Responsibility. 7. Quantity of work. 8. Work quantity. 9. Punctuality of time. 10. Work effectiveness. 11. Independence. 12. Work Commitment. The data obtained in the field were analyzed based on the classification of the informants' answers which were described in the results and discussion of the research which was then carried out by the interpreter of the researcher. It is known that the Quality, Quantity and Performance (K3) of employees at the Central Bureau of Statistics of Kerinci Regency have been carried out properly according to its rules and main duties, only one research indicator that has not been implemented is the indicator of independence. Where employees are not all independent in carrying out tasks such as new employees and employees who occupy a room or work with new job duties. For this reason, the authors suggest that employees at the Central Statistics Agency of Kerinci Regency can maintain and continue to strive to continue to do innovation and creativity in work and increase employee Independence.
\end{abstract}

Keywords: Quality, Quantity, Employee Performance. 


\begin{abstract}
ABSTRAK
Analisis Kualitas, Kuantitas dan Kinerja (K3) Pegawai Pada Badan Pusat Statistik Kabupaten Kerinci. Badan Pusat Statistik merupakan organisasi yang telah ditetapkan berdasarkan Peraturan Presiden Nomor 86 Tahun 2007 tentang Badan Pusat Statistik dan Peraturan Kepala Badan Pusat Statistik Nomor 7 Tahun 2008 tentang Organisasi dan Tata Kerja Badan Pusat Statistik yang berada di Kabupaten Kerinci. Perumusan masalah penelitian yaitu, bagaimanakah Kualitas, Kuantitas dan Kinerja (K3) Pegawai Pada Badan Pusat Statistik Kabupaten Kerinci? Tujuan penelitian yaitu, Untuk mengetahui Kualitas, Kuantitas dan Kinerja (K3) Pegawai Pada Badan Pusat Statistik Kabupaten Kerinci. Penelitiaan ini menggunakan pendekatan kualitatif dimana data diperoleh melalui pedoman wawancara dilapangan kepada 7 orang informan yang mengacu kepada indikator penelitian yaitu 1 . Pengetahuan. 2. Keterampilan. 3. Kemampuan 4. Jumlah Jam Kerja. 5. Penggunaan waktu. 6. Tanggung jawab. 7. Kualitas kerja. 8. Kuantitas kerja. 9. Ketepatan waktu. 10. Efektifitas kerja. 11. Kemandirian. 12. Komitmen Kerja. Data yang diperoleh dilapangan dianalisis berdasarkan pengklasifikasian jawaban informan yang diuraikan dalam hasil dan pembahasan penelitian yang kemudian dilakukan interpretatif peneliti. diketahui bahwa Kualitas, Kuantitas dan Kinerja (K3) pegawai Pada Badan Pusat Statistik Kabupaten Kerinci sudah terlaksana dengan baik sesuai dengan atuiran dan tupoksinya, hanya satu indikator penelitian yang belum terlaksana yaitu indikator kemandirian. Dimana pegawai belum semuanya mandiri dalam melaksanakan tugas seperti pegawai baru dan pegawai yang menempati ruangan atau kerja dengan tupoksi kerja yang baru. Untuk itu penulis menyarankan agar pegawai Pada Badan Pusat Statistik Kabupaten Kerinci dapat mempertahankan dan terus berupaya untuk terus melakukan inofasi dan kreatifitas

Dalam bekerja dan meningkatkan kemandirian kerja pegawai.
\end{abstract}

\title{
Kata Kunci : Kualitas, Kuantitas, Kinerja Pegawai
}

\section{PENDAHULUAN}


Secara umum pada suatu organisasi perlu adanya kualitas kerja, bukan hanya sekedar kuantitas. Pada setiap organisasi khususnya organisasi pemerintah kuantitas pegawai lebih banyak tetapi tidak tertata dengan baik yaitu tidak maksimalnya menempatan pegawai yang berdasarkan keahlian dan kebutuhan. Bahkan kuantitas yang banyak masih saja terdapat kekurangan di sana-sini dalam penyelesaian pekerjaan. Setiap pegawai harus siap melaksanakan tugas yang telah menjadi tujuan dari suatu organisasi yang membutuhkan kemampuan yang maksimal dari pegawai dimana kemampuan tersebut sangat ditentukan dari kualitas seperti tingkat pendidikan, latihan, motivasi kerja, etos, mental dan kemampuan fisik pegawai. Azhari (2011:36)

Adanya kuantitas pegawai tetapi tidak diiringi dengan kualitas maka sudah jelas akan menimbulkan persoalan terhadap tujuan yang ingin dicapai oleh suatu Organisasi. Disinilah munculnya suatu persoalan terhadap membangun kinerja pegawai secama maksimal dan optimal. Untuk itu perlu adanya keseimbangan antar jumlah pegawai dengan kerja yang akan dilaksanakan agar tidak terjadinya Suatu keadaan dimana pegawai yang di gaji dapat memberikan kualitas kerja yang maksimal bukan kerja dilakukan oleh pegawai tidak tetap sementara yang mendapat hasil dari kinerjanya adalah pegawai tetap.

Kualitas kerja merupakan suatu hasil yang dapat diukur dengan efektifitas dan efisiensi suatu pekerjaan yang dilakukan oleh sumber daya manusia atau sumber daya lainnya dalam pencapaian tujuan atau sasaran organisasi dengan baik dan berdaya guna. Hal inilah yang menyebabkan antara organisasi yang satu dengan organisasi yang lain akan bersaing dalam hal meningkatkan kualitas, baik itu kualitas peningkatan sumber daya manusia maupun kualitas produk.

Peningkatan sumber daya manusia merupakan suatu kegiatan yang dilaksanakan bersama-sama pegawai dan manajer dengan tujuan mencari nilai tambah agar kualitas kerja dapat tercapai dalam suatu pekerjaan yang dilakukan oleh sumber daya manusia atau sumber daya lainnya dalam pencapaian tujuan atau sasaran organisasi denga baik dan berdaya guna. Karena pada dasarnya untuk melihat sampai sejauh mana peranan sumber daya manusia dalam suatu organisasi, maka dapat dilihat dari hasil kerja seorang pegawai yang ada dalam organisasi tersebut.

Badan Pusat Statistik adalah Lembaga Pemerintah Non-Departemen yang bertanggung jawab langsung kepada Presiden. Sebelumnya, BPS merupakan Biro Pusat Statistik, yang dibentuk berdasarkan Undang-Undang Nomor 6 Tahun 1960 tentang Sensus dan Undang-Undang Nomer 7 Tahun 1960 tentang Statistik. Sebagai pengganti kedua Undang-Undang tersebut ditetapkan Undang-Undang Nomor 16 Tahun 1997 tentang Statistik. Berdasarkan Undang-Undang ini yang ditindaklanjuti dengan peraturan perundangan dibawahnya, secara formal nama Biro Pusat Statistik diganti menjadi Badan Pusat Statistik

Badan Pusat Statistik merupakan organisasi yang telah ditetapkan berdasarkan Peraturan Presiden Nomor 86 Tahun 2007 tentang Badan Pusat Statistik dan Peraturan Kepala Badan Pusat Statistik Nomor 7 Tahun 2008 tentang Organisasi dan Tata Kerja Badan Pusat Statistik yang berada di Kabupaten Kerinci. Dalam hal ini sangat dibutuhkan karena memiliki tugas dalam membantu pemerintah di bidang statistik dengan keberadaan yang handal dibidangnya yang tidak hanya memiliki kuantitas kerja tetapi kualitas kerja dalam mewujudkan kinerja yang maksimal.

Berdasarkan uraian diatas dari pengamatan dan survey awal penulis pada Badan Pusat Statistik diindikasikan bahwa fenomena yang ditemui yaitu: 
1. Kualitas kerja pegawainya masih rendah, seperti kurangnya pembinaan terhadap pegawai dalam meningkatkan kinerja pegawai di bidang statistik.

2. Dari segi kuantitas pegawai yang bekerja secara tetap belum memenuhi kebutuhan kerja dalam artian kurangnya tenaga pegawai tetap sehingga perlu adanya tenaga honorer yang mendukung kerja dari pegawai (tidak berimbang kuantitas kerja dengan jumlah pegawai tetap yang hanya 20 orang).

3. Kinerja pegawai belum maksimal dalam melaksanakan tugasnya dalam pembinaan dan pelayanan administrasi umum dibidang perencanaan umum dan ketatausahaan.

4. Masih seringnya pekerjaan dilakukan dalam jangka waktu lama yang seharusnya bisa diselesaikan dalam waktu yang lebih singkat.

5. Masih ditemukannya kurang tanggungjawab pegawai dengan adanya berkasberkas pengurusan dari masyarakat yang hilang atau tidak ditemukan.

\section{METODE PENELITIAN}

\section{Metode Penelitian}

\section{Pendekatan Penclitiaa}

Dalam Penelitian ini penulis menggunakan pendekatan Kualitatif yaitu meneliti suatu objek penelitian dengan mengkaii secara keseluruhan dan mendalam bukan melihat hubungan dua variabel atau lebih. Dimana hasil penelitian akan diolah berdasarkan interpretatif peneliti dan dinraikan dalam bentuk deskriptif. Sugiono, (2007:42)

\section{Informan Penelitian dan Teknik Penentuan Informan Informan Penelitian}

Menurut Sugiono, (2007:91), metode penarikan informan adalah merupakan teknik pengambilan sampel untuk menentukan sampet yang akan digunakan dalam penelitian. Dalam penelitian kualitatif proses sampling yang terpenting adalah bagaimana menentukan informan kunci atau situasi sosial tertentu yang sarat formasi sesuai dengan fokus penekan.

Dalam menentukan informan yang akan dipakai dalam suatu penelitian, ada lima kriteria untuk pemilihan informan yaitu :

1. Subjek yang telah cukup lama dan intensif menyatu dengan kegiatan atau aktifitas yang menjadi informasi:

2. Subjek yang masih terlibat secara penuh/aktif pada lingkungan atau kegiatan yang menjadi perhatian peneliti.

3. Subjek yang mempunyai cukup banyak waktu atau kesempatan untuk diwawancarai.

4. Subjek yang dalam memberikan informasi tidak cenderung diolah atas dipersiapkan terlehih dahulu.

5. Subjek sebelumnya tergolong masih "asing" dengan penelitian, sehingga peneliti merasa tertantang untuk belajar sebanyak mungkin dari subjek yang berfungsi sebagai "guru baru' bagi peneliti.

Kriteria informan dalam penelitian ini yaitu, kepala Kantor pusat statistik, pegawai tetap kantor pusat statistik dan masyarakat yang memiliki usia diatas 20 tahun atau yang sudah dewasa sehingga dalam pengambilan data informan pengerti dengan apa yang diamksud oleh peneliti. 


\section{Teknik Penentaan Informan}

Dalam penelitian ini teknik penentuan informan mengacu kepada pendapat Bugin, (2093:53). Pemilihan informan kunci dan informan biasa dilakukan dengan cara purposife sampling (sampel terpilih) yang dipilih atau ditentukan oleh peneliti yaitu kepala dan pegawai yang bekerja di kantor Badan Pusat Statistik dan masyarakat Kabupaten Kerinci.

Kriteria informan dalam penelitian ini yaitu, kepala Kantor pusat statistik, pegawai tetap kantor pusat statistik dan masyarakat yang memiliki usia diatas 20 tahun keatas sehingga dalam pengambilan data informan pengerti dengan apa yang dimaksud oleh peneliti yaitu penulis mengambil informan dengan kriteria, yaitu : kepala bagian, pegawai kantor Badan Pusat Statistik Kabupaten Kerinci. Tabel informan penelitian dapat ditihat dibawah ini.

Tabel 1.1

Informan penelitian

\begin{tabular}{|c|c|c|c|}
\hline NO & NAMA & JABATAN & KET \\
\hline 1. & Revia Hendrita,SP,.MAP & Kepala BPS kab.Kerinci & Informan kunci \\
\hline 2. & Iwan Z,S.ST & Kasi Statistik Sosial & Informan Biasa \\
\hline 3. & Wirdianto,SP & Kasi Statistik Distribusi & Informan Biasa \\
\hline 4. & Ainil Mardiah & Staf Subag tata usaha & Informan Biasa \\
\hline 5. & Roro Tenty,ST & Staf seksi IPDS & Informan Biasa \\
\hline 6. & Alfian,SE & Bendahara Pengeluaran & Informan Biasa \\
\hline 7. & Neva Julia Rahman,SE & Staf Subag tata usaha & Informan Biasa \\
\hline \multicolumn{3}{|c|}{ Jumlah = 7 Orang } \\
\hline
\end{tabular}

Sumber: kantor badan pusat statistic kabupaten Kerinci 2020

\section{Data Yang Akan diambil}

Untuk keperluan penelitian ini, adapun jenis data yang penulis ambil adalah menurut pendapat Lexy J.Moleong (2009: 21):

1. Data Primer, yaitu data yang diperoleh dari hasil penelitian langsung ke lapangan atau ke tempat penelitian melalui wawancara agar data yang didapatkan tepat dan benar melalui kantor Badan Pusat Statistik Kabupaten Kerinci.

2. Data Sekunder, yaitu data yang diperoleh dari dokumen, arsip-arsip dan sumber lainnya yang berkaitan dengan penelitian ini, yang dapat menunjang penelitian dengan melihat relefansinya dengan permasalahan pelitian

\section{Teknik Pengumpulan Data dan Alat Analisis Data} Teknik Pengumpulan Data

\section{Penelitian Perpustakaan (Library Research)}

Penelitian ini untuk mendapatkan data sekunder yaitu data yang diperoleh dilapangan melalui literatur-literatur ataupun referensi-referensi, untuk mencari landasan teori yang berhubungan dengan masalah yang dibahas, serta buku-buku yang menunjang proposal penelitian ini.

2. Penelitian Lapangan (Field Research)

Penelitian ini merupakan pengumpulan data yang dilakukan dengan cara turun langsung ke objek yang di teliti untuk mendapatkan data primer dengan cara:

1. Wawancara (interview) 
Menurut Sugiyono, (2007:222), wawancara adalah teknik pengumpulan data yang melakukan percakapan antara dua orang atau lebih, yang pertanyaannya diajukan oleh peneliti kepada subjek atau sekelompok subjek penelitian untuk dijawab. Danim, (2002:130). Wawancara yang dilakukan adalah wawancara tidak tersrtuktur, adalah wawancara yang bebas dimana peneliti tidak menggunakan pedoman wawancara yang telah tersusun secara sistematis dan lengkap untuk pengumpulan datanya. Pedoman wawancara yang digunakan hanya berupa garisgaris besar permasalahan yang akan ditanyakan.

\author{
Alat Analisis Data \\ Dalam penelitian alat analisis data yang digunakan yaitu: \\ 1. Pedoman wawancara \\ 2. Alat perekam \\ 3. HP \\ 4. Pena/ Pensil \\ 5. Buku
}

\title{
Unit Analisis
}

Yang menjadi unit analisis dalam penelitian ini adalah kepala kantor, pegawai di Kantor Badan Pusat Statistik Kabupaten Kerinci, dan masyarakat Kabupaten Kerinci

\section{Interprestasi Data}

Interprestasi Data yang digunakan mengacu pada tujuan penulisan ini yakni untuk mengatahui kualitas, kuantitas dan kinerja pegawai Badan Pusat Statistik Kabupaten Kerinci. Peneliti menggunakan informan kunci dan biasa berdasarkan tingkat kejenuhan yang akan diperoleh dalam penelitian nantinya yang akan diwawancarai dengan menggunakan pedoman wawancara untuk memperoleh data dilapangan.

Metode analisis yang digunakan dalam penelitian ini yaitu data yang diperoleh dilapangan dan diolah dengan menggunakan interpretatif peneliti untuk mengolah data mentah yang relevan yang diperoleh dilapangan kemudian hasil penelitian diuraikan dalam bentuk kalimat bukan angka-angka atau data statistik.

Menurut Miles dalam Emzir (2010 : 129) Analisa data ada tiga cara yaitu :

1. Reduksi data

Reduksi data merupakan suatu bentuk analisis yang mempertajam, memilih ,memfokuskan, membuang, dan menyusun data dalam suatu cara dimana kesimpulan akhir dapat diverifikasi. Data kualitatif dapat direduksi dan ditransformasikan dalam banyak cara yaitu melalui seleksi halus, melaluirangkuman atau parafrase.

2. Model data (data display)

Langkah kedua dari kegiatan analisis data merupakan model data. Model (display) dalam kehidupan sehari-hari berbeda-beda dari pengukuran bensin, surat kabar, sampai layar computer. Melihat sebuah tanyangan membantu kita memahami apa yang terjadi dan melakukan sesuatau-analisis lanjutan atau tindakan didasarkan pada pemahaman tersebut.

Bentuk yang paling sering dimodel data kualitatif selama ini adalah teks naratif. Manusia tidak terlalu kuat sebagai pemproses dari sejumlah besar informasi : tendensi kognitif merupakan mereduksi inforrmasi yang komplek kedalam berbagai gestalt yang dipilih atau konfigurasi-konfigurasi yang mudah dipahami. Model tersebut mencangkup berbagai jenis matrik, grafik, jaringan kerja, dan bagan. 
Merancang kolom dan baris dari suatu matrik untuk data kualitanf dan menentukan data yang mana, dalam bentuk yang mana, harus dimasukan kedalam sel yang mana merupakan aktivitas analisis.

3. Penarikan Kesimpulan/Verifikasi

Langkah ketiga dari aktivitas analisis merupakan penarikan dan berifikasi kesimpulan. Kesimpulan akhir tergantung pada ukuran korpus dari catatan lapangan , penyimpangan, dan metode-metode perbaikan yang digunakan tuntutan dari penyandang dan tetapi kesimpulan bahkan ketika seorang menyatakan telah memproses secara induktif.

Untuk menjaga validitas data maka dilakukan triangulasi terhadap sumber dan data.

1. Triangulasi sumber, dilakukan dengan cara :

a. Pengecekan data dan membandingkan fakta dengan sumber lain, sumber tersebut berupa informan yang berbeda.

b. Membandingkan data dengan memasukkan kategori informan yang berbeda.

2. Triangulasi data, dilakukan dengan cara :

Meminta umpan balik dari informan, umpan balik tersebut berguna untuk memperbaiki kualitas data dan kesimpulan yang ditarik dari data tersebut.

\section{HASIL DAN PEMBAHASAN}

\section{Analisis Kualitas, Kuantitas dan Kinerja (K3) Pegawai Pada Badan Pusat Statistik Kabupaten Kerinci}

Dalam penelitian ini dilakukan pengambilan data dilapangan dengan menggunakan pedoman wawancara dengan 7 orang informan di Badan Pusat Statistik Kabupaten Kerinci dari tanggal 27 Oktober sampai tanggal 07 Oktober 2020 kemudian data diuraikan berdasarkan urutan indikator dari setiap informan, setelah itu dilakukan kesimpulan berdasarkan interpretatif dari peneliti pada setiap indikator penelitian.

\section{Operasional Variabel}

Kerangka konseptual untuk kualitas kerja diambil menurut Zeithaml (2007: 29) indikator kualitas kerja mengacu pada kualitas sumber daya manusia. Indikator kualitas kerja ada 3 yaitu

1. Pengetahuan

Kemampuan yang berpatok dan berorintasi pada tingkat intelijensi,daya fikir dan penguasaan ilmu dengan ruang lingkup yang sangat luas.

2. Keterampilan

Mencakup kemampuan dan penguasaan operasional dan hal teknik pada suatu bidang tertentu.

3. Kemampuan

Sesuatu yang terbentuk karena kompetensi yang dimiliki seseorang mencakup kerjasama, loyalitas, kedisiplinan dan tanggung jawab.

Kerangka konseptual dari kuantitas kerja diambil menurut Mangkunegara (2009:58) yaitu :

1. Jumlah Jam Kerja

Kuantitas kerja yang dimaksud adalah banyaknya pekerjaan yang dapat diselesaikan oleh pegawai dalam kurun waktu yang telah ditentukan. Jika jumlah pekerjaan yang dapat diselesaikan pegawai semakin banyak, maka semakin baik pula kinerja yang dihasilkan.

2. Penggunaan waktu

Pegawai yang senantiasa berusaha menyelesaikan pekerjaan yang diberikan dengan tepat waktu dan tidak menyia-nyiakan waktu dalami menyelesaikan pekerjaan 
3. Tanggung Jawab

Menunjukkan tanggung jawab yang sangat besar terhadap pekerjaan yang diberikan dan berkeinginan untuk selalu melakukan pekerjaan dengan baik dau penuh rasa tanggungjawab.

Sedangkan kerangka kanseptuat Kinerja diamati. darr pendapat Soedjono,. (2005:15) yaitu:

1. Kualitas Kerja

Hasil pekerjaan yang dilakukan mendekati sempurna atau memenuhi tujuan yang diharapkan dari pekerjaan tersebut.

2. Kuantitas Kerja Jurntah yang dihasitkan atau jumtah aktivitas yang dapat diselasaikan.

3. Ketepatan Waktu

Dapat menyelesaikan pada waktu yang telah ditetapkan serta memaksimalkan waktu yang tersedia untuk aktivitas yang lain.

4. Efektivitas

Pemanfaatan secara maksimal suraber daya yang ada pada organisasi untuk. meningkatkan keuntungan dan mengurangi kerugian.

5. Kemandirian

Dapat melaksanakan kerja tanna bantuan guna menghindari basil yang merugikan.

6. Komitmen kerja

Komitmen kega antara pegawar dengan organisasinya dan tanggung jawab pegawai terhadap organisasinya.

\section{Hasil Penelitian}

\section{Pengetahuan}

Kemampuan yang berpatok dan berorintasi pada tingkat intelijensi, daya fikir dan penguasaan itu dengan ruang lingkup yang sangat luas.

Wawancara dengan informan tentang bagaimanakah kualitas pengetahuan pegawai pada Badan Pusat Statistik Kabupaten Kerinci ? Jawaban dari informan Yaitu:

"Kualitas pengetahuan pegawai Badan Pusat Statistik cukup tinggi dimana. mayoritas pegawai memiliki pendidikan tingkat sarjana." (Hasil wawancara dengan Bapak Refia Hendrita pukul 11.30 Wib hari Selasa tanggal 27 Oktober 2020)

"Pengetahuan pegawai 60\% memiliki pendidikan tingkat sarjana atau S1 dan sehagian besar memiliki pendidikan yang sesuai dengan bidang pekerjaannya." (Hasil wawancara dengan Bapak Iwan pukul 10.00 Wib hari Rabu tanggat 28 Oktober 2020) "Kualitas pengetahuan pegawai cukup bagus hal ini dbuktikan banyak pegawai yang sudah sarjana statistik dan memiliki pengetahuan dibidang nya masing-masing" (Hasil wawancara dengan Bapak Wirdianto. pukut 11.90 Wib hari Kamis tanggal 29 Oktober 2020)

"Pengetahuan pegawai cukup tinggi dengan penguasaan dibidangnya kerjanya dan cakap dalam melaksanakan tugasnya." (Hasil wawancara dengan Ibu Aini) Mardiah pukul 11.15 Wib hari Senin 2 November 2020)

"Kualitas kerja pegawai dalam pengetahuan cukup tinggi dan memiliki keahiian dibidangnya masing-masing." (Hasil wawancara dengan Ibu Roro, pukul 09.00 Wib hari Rabu 4 November 2020)

"Pegawai pada badan pusat statistik Kabupaten Kerinci memiliki pengetahuan yang cukup dibidangnya karena sudah banyak yang sarjana dan cukup menguasai pekerjaannya masing-masing." (Hasil wawancara dengan Bapak Alfian pukul 11.15 Wib hari Kamis 5 November 2020) 
"Badan pusat statistik memiliki pegawai yang cukup handal dibidangnya karena sudah banyak yang tamatan sarjana." (Hasil wawancara dengan Ibu Neva, pukul 09.00 Wib hari Sabtu 7 November 2020)

Dari jawaban informan dapat diinterprstasikan bahwa pengetahuan pegawai pada Badan Pusat Statistik Kabupaten Kerinci sudah memadai karena sudah banyak yang sarjana dan memiliki penguasaan kerja dibidangnya masingmasing.

\section{Keterampilan} tertentu.

Mencakup kemampuan dan penguasaan operasional dan hal teknik pada suatu bidang

Wawancara dengan informan tentang bagaimanakah kualitas keterampilan pegawai pada Badan Pusat Statistik Kabupaten Kerinci? Jawaban dari informan yaitu :

"Keterampilan pegawai Badan Pusat Statistik sudah bagus, sudah memiliki kecakapan dibidangnya masing-masing dan handal dalam mengerjakan tugas kerja yang diberikan." (Hasil wawancara dengan Bapak Refia Hendrita pukul 11.30 Wib hari Selasa tanggal 27 Oktober 2020)

"Kualitas keterampilan pegawai cukup handal dan memitiki kecakapan dalam menyelesaikan pekerjaannya." (Hasil wawancara dengan Bapak Iwan pukul 10.00 Wib hari Rabu tanggal 28 Oktober 2020)

"Pegawai badan pusat statistik Kabupaten Kerinci sebagian besar sudah memiliki kualitas keterampilan sesuai bidang pekerjaannya." (Hasil wawancara dengan Bapak Wirdianto. pukul 11.00 Wib hari Kamis tanggal 29 Oktober 2020)

"Pengetahuan pegawai cukup tinggi dengan penguasaan dibidangnya kerjanya dan cakap dalam melaksanakan tugasnya." (Hasil wawancara dengan Ibu Ainil Mardiah pukul 11.15 Wib hari Senin 2 November 2020)

"Keterampilan pegawai cukup handal dan memiliki pengusaaan terhadap fasilitas yang disediakan sebagai penunjang pekerjaan." (Hasil wawancara dengan Ibu Roro, pukul 09.00 Wib hari Rabu 4 November 2020)

"Pegawai statistik memiliki keterampilan yang cukup dibidangnya karena sudah cakap dalam menyelesaikan pekerjaannya masing-masing." (Hasil wawancara dengan Bapak Alfian pukul 11.15 Wib hari Kamis 5 November 2020)

"Badan pusat statistik memiliki pegawai keterampilan yang cukup handal dibidangnya masibng-masing dimana dalam melakukan pekerjaan tidak membutuhkan waktu yang lama." (Hasil wawancara dengan Ibu Neva, pukul 09.00 Wib hari Sabtu 7 November 2020)

Dari jawaban informan dapat diinterprstasikan bahwa kualitas keterampilan pegawai badan pusat statistik Kabupaten Kerinci sudah cukup memadai hal ini dapat dibuktikan setiap pegawai memiiki kecakapan masingmasing dan dapat menyelesaikan pekerjaanya sesuai dengan tugas yang diberikan dan waktu yang telah ditentukan.

\section{Kemampuan}

Sesuatu yang terbentuk karena kompetensi yang dimiliki seseorang mencakup kerjasama, loyalitas, kedisiplinan dan tanggung jawab.

Wawancara dengan informan tentang bagaimanakah kualitas kemampuan pegawai pada Badan Pusat Statistik Kabupaten Kerinci? Jawaban dari informan yaitu :

"Kemampuan pegawai Badan Pusat Statistik dalam kedisiplinan dan memiliki tanggung jawab yang tinggi terhadap pekerjaan." (Hasil wawancara dengan Bapak Refia Hendrita pukul 11.30 Wib hari Selasa tanggal 27 Oktober 2020) 
"Kemampuan kerja pegawai bagus dimana setiap pegawai memioliki disiplin dan tanggugjawab yang tinggi dalam pekerjaan." (Hasil wawancara dengan Bapak Iwan pukul 10.00 Wib hari Rabu tanggal 28 Oktober 2020)

"Pegawai badan pusat statistik Kabupaten Kerinci sebagian besar sudah memiliki kemampuan kerja yang baik seperti memiliki kesanggupan dalam kerjasama dan loyalitas terhadap pekerjaandan personalia." (Hasil wawancara dengan Bapak Wirdianto. pukul 11.00 Wib hari Kamis tanggal 29 Oktober 2020)

"Kemampaun dalam melaksanakan tugas kerja cukup tinggi yang dibuktikan dengan disiplin dan tanggungjawab dalam menyelesaikan pekerjaannya." (Hasil wawancara dengan Ibu Ainil Mardiah pukul 11.15 Wib hari Senin 2 November 2020)

"Pegawai cukup memiliki kemampuan dalam melakukan pekerjaannya yang memiliki disiplin dan tanggungjawab." (Hasil wawancara dengan Ibu Roro, pukul 09.00 Wib hari Rabu 4 November 2020)

"Pegawai statistik memiliki kemampuan yang cukup dibidangnya karena setiap pegawai memiliki kerjasama dan tanggung jawab dalam bekerja." (Hasil wawancara dengan Bapak Alfian pukul 11.15 Wib hari Kamis 5 November 2020)

"Pegawai memiliki kemampuan yang handal dibidangnya masing-masing dan bertanggungjawab terhadapkerjanya serta disiplin." (Hasil wawancara dengan Ibu Neva, pukul 09.00 Wib hari Sabtu 7 November 2020)

Dari jawaban informan dapat diinterprstasikan bahwa kualitas kemampuan pegawai badan pusat statistik Kabupaten Kerinci dalam kerjasama, loyalitas, kedisiplinan dan tanggungjawab sudah cukup baik dimana setiap pegawai memiliki kemampuan dalam menyelesaikan pekerjaannya dengan penuh disiplin dan tanggungjawab serta dapat menjalin kerjasama terhadap personalia dan loyalitas yang tinggi terhadap pekerjaan.

\section{Jumlah Jam Kerja.}

Banyaknya pekerjaan yang dapat diselesaikan oleh pegawai dalam kurun waktu yang telah ditentukan. Jika jumlah pekerjaan yang dapat diselesaikan pegawai semakin banyak, maka semakin baik pula kinerja yang dihasilkan .

Wawancara dengan informan tentang bagaimanakah jumlah jam kerja pegawai pada

Badan Pusat Statistik Kabupaten Kerinci? Jawaban dari informan yaitu :

"Jumlah jam kerja sama dengan pegawai pada kantor lain dimana jam kerja sesuai dengan aturan jam kerja nasional jam 08.00 sampai jam 16.00 dan istirahat 2 jam dari jam 12.00 sampai dengan jam 14.00. hari kerja 5 hari senin sampai jumat, kecuali pada hari-hari besar atau libur nasional." (Hasil wawancara dengan Bapak Refia Hendrita pukul 11.30 Wib hari Selasa tanggal 27 Oktober 2020)

"Kuantitas jam kerja pcgawai badan pusat statistik Kabupaten Kerinci sama dengan jam kerja pegawai dikantor lainnya yaitu 5 hari kerja." (Hasil wawancara dengan Bapak Iwan pukul 10.00 Wib hari Rabu tanggal 28 Oktober 2020)

"Pegawai badan pusat statistik Kabupaten Kerinci memiliki kuntitas jam kerja sama dengan kantor atau instansi lain yaitu lima hari jam kerja dan dispensasi untuk pegawai yang memiliki halangan kehadiran dikarenakan sakit, izin ataupun karena ditugaskan dinas Juar oleh kantor." (Hasil wawancara dengan Bapak Wirdianto. pukul 11.00 Wib hari Kamis tanggal 29 Oktober 2020)

"Kuantitas jam kerja pegawai masuk jam 08.00 Wib dan pulang jam 16.00 Wib dan ini berlaku untuk semua pegawai karena jam kerja di kontrol dengan dengan sistem absensi kehadiran elektronik menggunakan absensi kontak mata." (Hasil wawancara dengan Ibu Ainil Mardiah pukul 11.15 Wib hari Senin 2 November 2020)

"Pegawai memiliki kuantitas jam kerja yang sama dengan pegawai di kantor lainnya dan wajib untuk menyelesaikan pekerjaan sesuai dengan jam kerja yang sudah 
ditetapkan." (Hasil wawancara dengan Ibu Roro, pukul 09.00 Wib hari Rabu 4 November 2020)

"Pegawai statistik memiliki jam kerja yang sama dan pekerjaan dikerjakan sesuai dengan beban jam kerja yang sudah ditetapkan." (Hasil wawancara dengan Bapak Alfian pukul 11.15 Wib hari Kamis 5 November 2020)

"Jam kerja pegawai dimulai dari jam 08.00 Wib sampai dengan jam 16.00 wib setiap hari dari Senin sampai Jumat dan setiap pegawai wajib melaksanakan jam kerjanya sesuai beban tugasnya masing-masing." (Hasil wawancara dengan Ibu Neva, pukul 09.00 Wib hari Sabtu 7 November 2020)

Dari jawaban informan dapat diinterprstasikan bahwa kualitas jumlah jam kerja pegawai badan pusat statistik Kabupaten Kerinci dalam melaksanakan Pekerjaannya sama dengan jumlah jam kantor lain yaitu mulai jam 08.00 Wib Sampai dengan 16.00 Wib setiap hari kerja yaitu hari Senin sampai Jumat sesuai beban kerja untuk masing-masing pegawai yang sudah ditetapkan sesuai dengan tupoksinya dan dispensasi bagi pegawai yang sakit, izin ataupun dinas luar serta libur kerja pada hari-hari besar atau libur nasional.

\section{Penggunaan waktu}

Pegawai yang senantiasa berusaha menyelesaikan pekerjaan yang diberikan dengan tepat waktu dan tidak menyia-nyiakan waktu dalam menyelesaikan pekerjaan.

Wawancara dengan informan tentang bagaimanakah penggunaan waktu pegawai pada

Badan Pusat Statistik Kabupaten Kerinci? Jawaban dari informan yaitu :

"Penggunaan waktu oleh pegawai cukup efisien yang harus dilaksanakan sesuai dengan tupoksinya masing-masing dan waktu yang sudah ditetapkan." (Hasil wawancara dengan Bapak Refia Hendrita pukul 11.30 Wib hari Selasa tanggai 27 Oktober 2020)

"Pegawai badan pusat statistik Kabupaten Kerinci memiliki penggunaan waktu kerja yang harus diselesaikan dengan beban kerjanya masingmasing berdasarkan tupoksinya." (Hasil wawancara dengan Bapak Iwan pukul 10.00 Wib hari Rabu tanggal 28 Oktober 2020)

"Setiap pegawai badun pusat statistik Kabupaten Kerinci wajib mengerjakan pekerjaan yang dibebankan sesuai dengan tupoksinya dan penggunaan waktu kerja yang tepat dan efisien agar tidak terjadi kelalaian dalam pekerjaan dan tidak menyianyiakan penggunaan waktu kerja." (Hasil wawancara dengan Bapak Wirdianto. pukul 11.00 Wib hari Kamis tanggal 29 Oktober 2020)

"Setiap pegawai memiliki waktu kerja yang penggunaannya harus sesuai beban kerja dan tupoksi kerja nya masing-masing serta tidak melakukan penyia-nyiakan penggunaan waktu kerja." (Hasil wawancara dengan Ibu Ainil Mardiah pukul 11.15 Wib hari Senin 2 November 2020)

"Pegawai harus dapat menggunakan waktu kerja seefisien mungkin agar tidak melakukan membuang-buang waktu kerja dan pegawai sudah melaksanakannya sesuai tupoksinya masing-masing." (Hasil wawancara dengan Ibu Roro, pukul 09.00 Wib hari Rabu 4 November 2020).

"Pegawai statistik sudah menggunakan waktu kerjanya dengan baik dan sesuai dengan tugas yang telah ditetapkan seperti tidak mengobrol selama jam kerja." (Hasil wawancara dengan Bapak Alfian pukul 11.15 Wib hari Kamis 5 November 2020).

"Penggunaan waktu kerja pegawai sudah dilaksanakan dengan baik sesuai dengan tupoksinya masing-masing dengan tidak melakukan pekerjaan membuang-buang waktu dalam jam kerja." (Hasil wawancara dengan Ibu Neva, pukul $\underline{09.00}$ Wib hari Sabtu 7 November 2020). 
Dari jawaban informan dapat diinterpretasikan bahwa penggunaan waktu kerja sudah dilaksanakan dengan baik oleh pegawai badan pusat statistik Kabupaten Kerinci dengan efisien sesuai dengan tupoksi tugas dan beban kerja nya masing-masing dengan tidak menyianyiakan waktu dan tidak melakukan kegiatan diluar tugas yang diberikan.

\section{Tanggung Jawab}

Menunjukkan tanggung jawab yang sangat besar terhadap pekerjaan yang diberikan dan berkeinginan untuk selalu melakukan pekerjaan dengan baik dan penuh rasa tanggungjawab.

Wawancara dengan informan tentang bagaimanakah tanggung jawab pegawai pada Badan Pusat Statistik Kabupaten Kerinci? Jawaban dari informan yaitu :

"Pegawai sudah menunjukkan tanggung jawab kerja yang cukup baik dimana setiap pegawai dapat menyelesaikan pekerjaan sesuai dengan jam kerja dan penggunaan waktu kerja yang cukup efisien dan memiliki tanggung jawab yang terhadap kerjanya." (Hasil wawancara dengan Bapak Refia Hendrita pukul 11.30 Wib hari Selasa tanggal 27 Oktober 2020)

"Pegawai badan pusat statistik Kabupaten Kerinci memiliki penggunaan waktu kerja yang harus diselesaikan dengan beban kerjanya masingmasing berdasarkan tupoksinya." (Hasil wawancara dengan Bapak Iwan pukul 10.00 Wib hari Rabu tanggal 28 Oktober 2020)

"Setiap pegawai badan pusat statistik Kabupaten Kerinci wajib memiliki tanggung jawab yang tinggi terhadap pekerjaannya dan dalam hal ini pegawai sudah melaksanakan tugas kerja mereka dengan penuh tanggung jawab." | (Hasil wawancara dengan Bapak Wirdianto. pukul 11.00 Wib hari Kamis tanggal 29 Oktober 2020)

"Pegawai sudah memiliki tanggung jawab yang tinggi terhadap pekerjaan mereka sesuai dengan tukopsinya masing-masing." (Hasil wawancara dengan Ibu Ainil Mardiah pukul 11.15 Wib hari Senin 2 November 2020)

"Pegawai sudah melakukan tanggung jawab dalam melakukan pekerjaan dimana sestiap pegawai dapat menyelesaikan pekerjaannya sesuai dengan tugasnya masingmasing kalau ada pekerjaan yang belum selesai maka dengan penuh tanggung jawab diselesaikan dengan tuntas dengan tidak mempengaruhi kerja pegawai yang lain." (Hasil wawancara dengan Ibu Roro, pukul 09.00 Wib hari Rabu 4 November 2020)

"Pegawai badan pusat statistik Kabupaten Kerinci sudah melakukan pekerjaannya dengan penuh tanggungjawab, dimana setiap pengurusan dapat diselesaikan sesuai dengan waktu yang telah ditentukan." (Hasil wawancara dengan Bapak Alfian pukul 11.15 Wib hari Kamis 5 November 2020)

"Pegawai sudah melakukan pekerjaannya dengan baik dan penuh rasa tanggungjawab dalam mengerjakan pekerjaannya baik memberikan pelayanan kepada amsyarakat ataupun pengurusan pekerjaan internal kantor itu sendiri." (Hasil wawancara dengan Ibu Neva, pukul 09.00 Wib hari Sabtu 7 November 2020)

Dari jawaban informan dapar Sinterprerasikao panwa pegawai suddn memilikk tanggungjawab dalam sctaksanakan pekerjaannya baik dalam memberikan pelayanan kepada masyarakat ataupun melakukan tugas kerja yang telah dibehankan kepada setiap netwak Sesnat engan.

\section{Kuslitas Kerja}

Hasil pekerjaan yang dilakukan mendekati sempuma atav memenuhi utuan yang drinarapkaa dari mekecraaa tersenut. 
Wawancara dengan informan tentang bagaimanakah kualitas kerja pegawai pada Badan Pusat Statistik Kabupaten Kerinci? Jawaban dari informan yaitu :

"Kualitas kerja pegawai sudah cukup baik dimana setiap segawai menutikk komitmen untuk mengerjakan pekerjaan mereka secara maksimal." (Hasil wawancara dengan Bapak Refia Hendrita pukui 11.30 Wib hari Selasa tanggal 27 Oktober 2924)

"Pegawai badan pusat statistik Kabupaten Kerinci memiliki kerja yang cukup berkualitas dimana setiap pegawai memilik tanggungjawab, disiplin dan penggunaan waktu kerja yang maksimal." (Hasil wawancara dengan Bapak Iwan pukul 10.00 Wib hari Rabu tanggal 28 Oktober 2020)

"Kualitas pegawai badan pusat statistik Kabupaten Kerinci sudah memiliki kualitas kerja yang baik hal ini dibuktikan dengan tugas kerja yang dapat diselesaikan dengan tepat waktu dan penuh dengan tanggung jawab." (Hasil wawancara dengan Bapak Wirdianto. pukul 11.00 Wib hari Kamis tanggal 29 Oktober 2020)

"Pegawai sudah memiliki kualitas kerja dengan melaksanakan tugas-tugas mereka dengan baik sesuai dengan tupoksinya." (Hasil wawancara dengan Ibu Ainil Mardiah pukul 11.15 Wib hari Senin 2 November 2020)

"pegawai sudah memiliki kualitas kerja yang cukup baik dengan melakukan pekerjaan sesuai dengan ketetapan waktu dan melakukan pekerjaan dengan penuh tanggung jawab efisien." (Hasil wawancara dengan Ibu Roro, pukuk 09.00 Wib hari Rabu 4 November 2020)

"Pegawai badan pusat statistik Kabupaten Kerinci sudah melakukan pekerjaannya sesuai dengan tujuan yang diharapkan dan melaksanakan tugas dengan baik." (Hasil wawancara dengan Bapak Alfian pukul 11.15 Wib hari Kamis 5 November 2020)

"Pegawai sudah melakukan pekerjaannya dengan baik dan penuh rasa tanggungjawab dan sesuai dengan tujuan yang telah ditetapkan sebelumnya berdasarkan tupoksi dari masing-masing pegawai." (Hasil wawancara dengan Ibu Neva, pukul 09.00 Wib hari Sabtu 7 November 2020)

Dari jawaban informan dapat diinterpretasikan bahwa pegawai sudah memiliki kualitas kerja dimana pekerjaan dilakukan dengan baik sesuai dengan tujuan yag telah ditetapkan berdasarkan tupoksi dari masing-masing pegawai.

\section{Kuantitas Kerja}

Jumlah yang dihasilkan atau jumlah aktivitas yang dapat diselesaikan.

Wawancara dengan informan tentang bagaimanakah kuantitas kerja pegawai pada Badan Pusat Statistik Kabupaten Kerinci? Jawaban dari informan yaitu :

"Kuantitas kerja pegawai sudah cukup baik dimana setiap pegawai setatu berusaha untuk melakukan pekerjaan dengan baik dan maksimal secara kuantitas." (Hasil wawancara dengan Bapak Refia Hendrita pukul 11.30 Wib hari Selasa tanggal 27 Oktober 2020)

"Pegawai pada badan pusat statistik Kabupaten Kerinci tetah melakukan pekerjaannya sesuai kuntitas kerja yang ditugaskan.” (Hasil wawancara dengan Bapak Iwan pukul 10.00 Wib hari Rabu tanggal 28 Oktober 2020)

"Pekerjaan secara kuantitas telah dilakukan secara maksimal oleh pegawai pada badan pusat statistik Kabupaten Kerinci dan selalu berupaya untuk dapat menyelesaikan pekerjaan sesuai dengan tupoksinya." (Hasil wawancara dengan Bapak Wirdianto. pukul 11.00 Wib hari Kamis tanggal 29 Oktober 2020)

"Pada prinsipnya pegawai sudah memiliki kuantitas kerja yang maksimal dengan melaksanakan tugas-tugas mereka dengan baik sesuai dengan tupoksinya dan tugastugas lain sesuai arahan dari pimpinan." (Hasil wawancara dengan Ibu Aini! Mardiah pukul 11.15 Wib hari Senin 2 November 2020) 
"Setiap pegawai sudah memiliki kuantitas kerja yang cukup baik dengan melakukan pekerjaan sesuai dengan porsinya berdasarkan tupoksi dan arahan dari pimpinan." (Hasil wawancara dengan Ibu Roro, pukul 09.00 Wib hari Rabu 4 November 2020)

"Setiap pegawai badan pusat statistik Kabupaten Kerinci sudah melakukan pekerjaannya sesuai dengan kuantitas kerjanya masing-masing." (Hasil wawancara dengan Bapak Alfian pukul 11.15 Wib hari Kamis 5 November 2020)

"Pegawai sudah berusaha melakukan pekerjaannya dengan baik dan penuh rasa tanggungjawab dan sesuai dengan kuantitas kerjanya masing-masing." (Hasil wawancara dengan Ibu Neva, pukul 09.00 Wib hari Sabtu 7 November 2020).

Dari jawaban informan dapat diinterpretasikan bahwa pegawai sudah melakukan pekerjaan berdasarkan kuantitas kerja yang ditugaskan berdasarkan tupoksinya masingmasing dan sesuai arahan dari pimpinan.

\section{Ketepatan Waktu}

Dapat menyelesaikan pada waktu yang telah ditetapkan serta memaksimalkan waktu yang tersedia untuk aktivitas yang lain.

Wawancara dengan informan tentang bagaimanakah ketepatan waktu Pegawai pada Badan Pusat Statistik Kabupaten Kerinci? Jawaban dari informan Yaitu :

"Ketepatan waktu pegawai sudah dilakukan sesuai dengan beban kerjanya masingmasing." (Hasil wawancara dengan Bapak Refia Hendrita pukul 11.30 Wib hari Selasa tanggal 27 Oktober 2020)

"Pegawai pada badan pusat statistik Kabupaten Kerinci telah melakukan pekerjaannya sesuai dengan ketepatan waktu yang telah ditentukan." (Hasil wawancara dengan Bapak Iwan pukul 10.00 Wib hari Rabu tanggal 28 Oktober 2020)

"Setiap telah berupaya untuk dapat menyelesaikan pekerja mereka sesuai ketepatan waktu yang telah diberikan." (Hasil wawancara dengan Bapak Wirdianto. pukul 11.00 Wib hari Kamis tanggal 29 Oktober 2020)

"Pada dasarnya pegawai sudah memiliki ketepatan waktu kerja yang sudah maksimal dengan melaksanakan tugas-tugas mereka dengan baik sesuai dengan tupoksinya masing-masing." (Hasil wawancara dengan Ibu Ainil Mardiah pukul 11.15 Wib hari Senin 2 November 2020)

"Setiap pegawai sudah memiliki ketepatan waktu kerja yang cukup baik dengan melakukan pekerjaan secara maksimal." (Hasil wawancara dengan Ibu Roro, pukul 09.00 Wib hari Rabu 4 November 2020)

"Pegawai badan pusat statistik Kabupaten Kerinci sudah melakukan pekerjaannya sesuai dengan ketepatan waktu kerjanya masing-masing." (Hasil wawancara dengan Bapak Alfian pukul 11.15 Wib hari Kamis 5 November 2020)

"Pegawai sudah melakukan pekerjaannya dengan baik dan penuh rasa tanggungjawab dan sesuai dengan ketepatan waktu kerja ditugaskan kepada masing-masing pegawai." (Hasil wawancara dengan Ibu Neva, pukul 09.00 Wib hari Sabtu 7 November 2020)

Dari jawaban informan dapat diinterpretasikan bahwa pegawai sudah Inelakukan pekerjaannya berdasarkan ketepatan waktu kerja yang ditugaskan berdasarkan tupoksinya masing-masing dan berupaya untuk selalu dapat bekerja Secara maksimal dan menyelesaikan dengan tepat waktu.

\section{Efektivitas}

Pemanfaatan secara maksimal sumber daya yang ada pada organisasi untuk meningkatkan keuntungan dan mengurangi kerugian.

Wawancara dengan informan tentang bagaimanakah efektifitas kerja pegawai pada Badan Pusat Statistik Kabupaten Kerinci? Jawaban dari informan yaitu : 
"Pegawai sudah melakukan pekerjaannya seefektifitas mungkin sesuai dengan tupoksi kerjanya masing-masing." (Hasil wawancara dengan Bapak Refia Hendrita pukul 11.30 Wib hari Selasa tanggal 27 Oktober 2020)

"Setiap pegawai pada badan pusat statistik Kabupaten Kerinci telah melakukan pekerjaannya secara efektifitas sesuai dengan ketentuan yang telah ditetapkan.” (Hasil wawancara dengan Bapak Iwan pukul 10.00 Wib hari Rabu tanggal 28 Oktober 2020) "Pegawai sudah melakuka pekerjaannya seefektif mungkin dan hal ini telah dibuktikan dengan penyelesaikan kerja yang tepat waktu tidak melalikan tugas yang telah menjadi rutinitas setiap pegawai." (Hasil wawancara dengan Bapak Wirdianto. pukul 11.00 Wib hari Kamis tanggal 29 Oktober 2020)

"Setiap sudah memiliki tupoksinya maisng-masing yang harus dilaksanakan dalam pekerjaannya dan pegawai sudah melakukan pekerjaan secara efektif dan efisien." (Hasil wawancara dengan Ibu Ainil Mardiah pukul 11.15 Wib hari Senin 2 November 2020)

"Setiap pegawai sudah memiliki komitmen untuk selalu bekerja seefektif mungkin sesuai dngan tupoksinya." (Hasil wawancara dengan Ibu Roro, pukul 09.00 Wib hari Rabu 4 November 2020)

"pegawai badan pusat statistik Kabupaten Kerinci sudah melakukan pekerjaannya secara efektif yang mengacu kepada tupoksi kerjanya." (Hasil wawancara dengan Bapak Alfian pukul 11.15 Wib hari Kamis 5 November 2020)

"pegawai sudah melakukan pekerjaannya dengan baik dan efektif sesuai dengan tupoksinya." (Hasil wawancara dengan Ibu Neva, pukul 09.00 Wib hari Sabtu 7 November 2020)

Dari jawaban informan dapat diinterpretasikan bahwa pegawai sudah melakukan pekerjaannya secara efektif dimana dalam hal ini setiap pegawai dapat melaksanakan tugastugasnya berdasarkan tupoksi dan batas waktu kerja yang telah ditetapkan.

\section{Kemandirian}

Dapat melaksanakan kerja tanpa bantuan guna menghindari hasil yang merugikan.

Wawancara dengan informan tentang bagaimanakah kemandirian pegawai dalam melakukan pekerjaan pada Badan Pusat Statistik Kabupaten Kerinci ? Jawaban dari informan yaitu :

"Dalam kemandirian pegawai sudah cukup baik dalam menyelesaikan tugasya sendiri tampa mengganggu pekerja lain." (Hasil wawancara dengan Bapak Refia Hendrita pukul 11.30 Wib hari Selasa tanggal 27 Oktober 2020)

"Pada prinsipnya memang tugas-tugas yang diberikan harus dapat diselesaikan sendiri. Jika ada keterlambatan dalam penyelesaian dapat meminta bantuan kepada pegawai lain yang mau dan sanggupmuntuk menyelesaikannya." (Hasil wawancara dengan Bapak Iwan pukul 10.00 Wib hari Rabu tanggal 28 Oktober 2020)

"Untuk kemandirian memang belum sepenuhnya dapat dilaksanakan adakalanya tugas yang diberikan kepada salah satu pegawai tidak dapat dipahami maka pekerjaan ersebut biasanya oleh pimpinan menugaskan pegawai lain lebih paham untuk membantu dan menjelaskan." (Hasil wawancara dengan Bapak Wirdianto. pukul 11.00 Wib hari Kamis tanggal 29 Oktober 2020)

"Untuk kemandirian kadangkala ada juga pegawai yang belum dapat melaksanakan tugas mereka secara mandiri apalagi pegawai yang baru ditugaskan dikantor ini, biasanya dibantu oleh pegawai yang senior dan lcbih mengerti agar pekerjaan dapat diselesaikan tepat waktu." (Hasil wawancara dengan Ibu Ainil Mardiah pukul 11.15 Wib hari Senin 2 November 2020) 
"Secara kemandirian pegawai sudah cukup mandiri hanya saja kadangkala ada juga dibantu oleh pegawai lain agar pekerjaan tersebut dapat selesaai dengan tepat waktu dan tidak menumpuk hal ini ada yang merupakan inisisatif dari pegawai ataupun ada yang memalui perintah dari pimpinan, tetapi secara keseluruhan pekerjaan dapat diselesaikan dengan baik." (Hasil wawancara dengan Ibu Roro, pukul 09.00 Wib hari Rabu 4 November 2020)

"Setiap pegawai diwajibkan dapat menyelesaikan pekerjaannya masingmasing, terkadang memang ada yang tidak memahami pekerjaannya karena pegawai baru dan begitu juga pada pegawai lain yang sudah lama mengalami kendala baik secara waktu atau karena faktor lain maka pegawai lain dapat membantu agar pekerjaan tersebut tidak terbengkalai." (Hasil wawancara dengan Bapak Alfian pukul 11.15 Wib hari Kamis 5 November 2020)

"Pada prinsipnya pegawai sudah dapat mengerjakan pekerjaan secara mandiri memang adakala dalam bekerja dibantu atau meminta bantuan kepada pegawai lain yang memahami pekerjaan tersebut." (Hasil wawancara dengan Ibu Neva, pukul 09.00 Wib hari Sabtu 7 November 2020)

Dari jawaban informan dapat diinterprstasikan bahwa secara kemandirian kerja dari pegawai masih belum maksimal karena masih ada pegawai yang belum dapat mengerjakan secara mandiri dan pimpinan memerintahkan pegawai lain yang lebih mengerti dan paham akan pekerjaan tersebut untuk membantu dan kadangkala dibantu berdasarkan inisiatif dari pegawai lain agar pekerjaan tersebut dapat dikerjakan tepat waktu agar pekerjaan lain tidak menumpuk karena masing-masing pekerjaan memiliki ketergantungan pada kerja yang lain atau saling keterhubungan.

\section{Komitmen Kerja}

Komitmen kerja antara pegawai dengan organisasinya dan tanggung jawab pegawai terhadap organisasinya.

Wawancara dengan informan tentang bagaimanakah komitmen kerja pegawai pada Badan Pusat Statistik Kabupaten Kerinci ? Jawaban dari informan yaitu :

"Setiap pegawai sudah memiiki komitmen dalam melakukan pekerjaannya dengan kedisiplin, tanggungjawab tepat waktu dan seefektif mungkin sesuai dengan tupoksinya masing-masing." (Hasil wawancara dengan Bapak Refia Hendrita pukul 11.30 Wib hari Selasa tanggal 27 Oktober 2020)

"Pada prinsipnya seiap pegawai memiliki komitmen daam pekerjaannya dimana setiap pegawai dapat melaksanakan tugasnya dengan baik dan selesai sesuai dengan waktu yang telah ditetantukan." (Hasil wawancara dengan Bapak Iwan pukul 10.00 Wib hari Rabu tanggal 28 Oktober 2020)

"Komitmen setiap pegawai dalam melaksankan tugasnya itu sangat penting dan disini pegawai sudah berusaha untuk berkomitmen dapat mengerjakan pekerjaanna dengan baik sesuai tuntutan kerja." (Hasil wawancara dengan Bapak Wirdianto. pukul 11.00 Wib hari Kamis tanggal 29 Oktober 2020)

"Untuk komitmen setiap pegawai sudah berkomitmen melaui fakta integritas untuk dapat bekerja dengan baik dan penuh kedisiplinan tanggung jawab yang tinggi terhadap pekerjaan." (Hasil wawancara dengan Ibu Ainil Mardiah pukul 11.15 Wib hari Senin 2 November 2020)

"Setiap pegawai wajib untuk berkimitmen dalam bekerja dan selalu berupaya untuk dapat bekerja dengan disiplin dan tanggujawab." (Hasil wawancara dengan Ibu Roro, pukul 09.00 Wib hari Rabu 4 November 2020) 
"Setiap pegawai diwajibkan dapat pekerja dengan baik dan berkomitmen dalam melaksanakan pekerjaannya dengan baik." (Hasil wawancara dengan Bapak Alfian pukul 11.15 Wib hari Kamis 5 November 2020)

"Pada prinsipnya pegawai sudah melakukan pekerjaan dengan disiplin dan anggung jawab serta komitmen yang tinggi terhadap pekrjaannya masing-masing." (Hasil wawancara dengan Ibu Neva, pukul 09.00 Wib hari Sabtu 7 November 2020)

Dari jawaban informan dapat diinterprstasikan bahwa secara komitmen kerja setiap pegawai pada Badan Pusat Statistik Kabupaten Kerinci sedah memiliki komitmen yang tinggi terhadap kerja dimana setiap pekerjaan diselesaikan tepat waktu penuh kedisiplinan dalam jam kerja dan bertanggungjawab terhadap setiap pekerjaan serta efektif dalam bekerja serta memiliki keterpaduan dalam menyelesaikan pekerjaan dengan baik.

\section{KESIMPULAN}

\section{Kesimpulan}

Dari uraian hasil penelitian dan pembahasan diatas dapat disimpulkan bahwa kualitas , kuantitas dan kinerja pegawai pada kantor Badan Puasat Statistik Kabupaten Kerinci adalah:

1. Secara kualitas kerja pegawai pada kantor Badan Puasat Statistik Kabupaten Kerinci sudah melaksanakan dengan baik seperti:

a. Pengetahuan

Pegawai sudah memiliki kemampuan bekerja berdasarkan pengetahuan yang dimiliki oleh pegawai dimana pegawai sudah memiliki pengetahuan yangcukup tinggi berdaasrkan jenjang pendidikan yang mayoritas sudah memiliki pendidkan sarjana (S1).

b. Keterampilan

Pegawai sudah memiliki kemampuan dan penguasaan operasional dan hal teknik pada suatu bidang tertentu terhadap maisng-masing pegawai dan pekerjaan dapat diselesaikan dengan baik sesuai dengan tupoksinya masingmasing.

c. Kemampuan

Pegawai sudah sudah melaksanakan pekerjaan mereka dengan baik dimana setiap pegawai dapat bekerjasama, loyalitas terhadap pekerjaan, kedisiplinan dan tanggung jawab yang cukup tinggi.

2. Berdasarkan kuantitas kerja padu setiap pegawai pada kantor Badan Pusat Statistik Kabupaten Kerinci sudah melaksanakan dengan baik seperti,

a. Jumlah jam Kerja.

Setiap pegawai sudah melakukan pekerjaan yang dapat diselesaikan oleh pegawai dalam kurun waktu yang telah ditentukan.

b. Penggunaan waktu

Pegawai sudah bekerja dengan baik dan dapat menyekesaikan pekerjaan yang diberikan dengan tepat waktu dan tidak menyia-nyiakan waktu dalam menyelesaikan pekerjaan.

c. Tanggung jawab

Setiap pegawai sudah menunjukkan tanggung jawab yang sangat besar terhadap pekerjaan yang diberikan dan berkeinginan untuk selalu melakukan pekerjaan dengan baik dan penuh rasa tanggung jawab.

3. Berdasarkan Kinerja setiap pegawai harus dapat bekerja sesuat dengan tupoksinya dan dapat bekerja dengan baik secara kualitas kerja , kuantitas kerja, ketepatan waktu, efektifitas, kemandirian dan komitmen kerja yang tinggi

a. Kualitas Kerja 
Hasil pekerjaan yang dilakukan sudah medekati sempurna atau memenuhi tujuan yang diharapkan dari pekerjaan tersebut.

b. Kuantitas Kerja

Jumlah kerja yang dihasilkan atau jumlah aktivitas yang dikerjakan sudah dapat diselesaikan dengan baik ssuai jadwal yang sudah ditetankan

c. Ketepatan Waktu

Setiap pegawai suad dapat menyelesaikan peekrjaannya masing-masing pada waktu yang telah ditetapkan serta memaksimalkan waktu yang tersedia untuk aktivitas yang tain.

d. Efektivitas

Setiap pegawai pada kantor Badan Pusat Statistik sudah dapat memanfaatkan waktu untuk dapat meyelesaikan pekerjaaan secara efisien dan maksimal.

e. Kemandirian

Dari sekian banyak indikator yang diujikan terhadap pegawai pada kantor Badan Pusat Statistik Kabupaten Kerinci ditemukan bahwa untuk kemandirian pegawai dalam melakukan pekerjaan masih belum maksimal dimana masih adanya pegawai yang tidak dapat melakukan pekerjaan secara mandiri sehingga butuh bantuan dari pegawai lain yang lebih pengerti baik diperintahkap dari atasan maupun atas inisiatif sendiri yang tinggi untuk dapat meyelesaikan pekerjaan secara keseluruhan hal ini biasa terjadi pada pegawai yang baru masuk ataupun pegawai lama yang kurang memahami pekerjaannya.

f. Komitmen Kerja

Pegawai sudah memiliki komitmen kerja yang baik antara pegawai dengan Organisasinya dan tanggung jawab pegawai terhadap organisasinya.

\section{UCAPAN TERIMAKASIH}

Diucapkan terima kasih kepada semua pihak yang telah berkontribusi dalam penulisan jurnal ini, sehingga jurnal ini dapat diselesaikan dengan baik. Dan juga terima kasih kepada penglola jurnal Qawwam, sehingga bisa dipublikasan di OJS Qawwam.

\section{DAFTAR PUSTAKA}

Arifin Abdurrahman. 2012. Mangjemen Sumber Daya Manusia. Jakarta: Rineka Cipta.

Anwar Prabu. 2013. Evaluasi Kinerja SDM. Bandung: PT Refika Aditama

Azhari2011. Mereformasi Birokrasi Publik Indonesia Yogyakarta: Pustaka Pelajar Offset.

Pebi Julianto. 2018. Pengaruh Pengetahuan dan Keterampilan Terhadap Prestasi Kerja Pegawai Pada Mtsn Model Sungai Penuh. E Jurnal Administrasi Nusantara. Sungai Penuh.

Bugin, B 2003, Analisis Data Penelitian Kualitarif, Rajawali Pers : Jakarta. Danjm, Sudarwan. 2002, Menjadi Peneliti Kualitatif, Pustaka Setia. Bandung Dunn, William N. 2003. Analisa kebijaksanaan Publik. Yogyakarta: Hanindita.

Flippo., Edwin. 2005, Manajemen Personalia, Edisi. 6, oleh Moh. Masud, SH, MA, Erlangga, Jakarta. 
Pebi Julianto. 2018. Pengaruh Sistem Kearsipan Terhadap Efisiensi Kerja Pada koantor Camat Air Hangat Kabupaten Kerinci. E Jurnal Administrasi Nusantara. Sungai Penuh.

Friedrick, Clayton. 2000, Policy Implementation. Jakarta : Erlangga.

Gibson, Ivancevich, Donnelly, 2002. Organisasi: Perilaku, Strukutr dan Proses, Jilid I dan Il, Edisi Bahawasa Indonesia Cetakan Ke 8. Bina Putera Aksara, Jakarta.

G.R. Terry. 2009. Manajemen Sumber Daya Manusia. CV.Andi Kuya Yogyakarta

Handoko. Hani T. 2003, Manajemen Personalia dan Sumber Daya Manusia, Edisi Ke-2, BPFE, Yogyakarta.

Harold Koontz and Weihnich, Heinz. 2006. Human Resources Management, McGraw-Hill Irwin.

Pebi Julianto. 2019. Pengaruh Disiplin Kerja Terhadap Prestasi Kerja Pegawai pada Puskesmas di kecamatan Depati VII Kabupaten Kerinci. E Jurnal Administrasi Nusantara. Sungai Penuh.

Hardjosoedarmo. 2006. Total Juality Management. Penerbit Andi. Yogyakarta

Hersey, Paul dan Kenneth H, Blanchard. 2007.Manajemen Perilaku Organisasi Pendayagunaan Sumberdaya Manusia. Edisi Keempat. Tejemahan Agus Dharma. Erlangga, Jakarta Juran. 2003.

Jualiry, Plaring and Analysis. Rajawali Pers. Jakarta Kamus besar bahasa Indonesia 2006. Edisi kedua. Balai Pustaka Jakarta.

Lexy J. Moleong. 2009. Metode Penelitian Kualitatif. Erlangga. Jakarta

Minto Rahayu. 2011. Bahasa Indonesia. Grasindo. Jakarta

Miles dan Emzir, 2010. Metodologi Penelitian Kualitatif Analisis Data, Jakarta: Rajawali Pers.

Mangkuprawira, TB Safri, 2003, Manajemen Sumber daya Manusia Strategik, Ghalia Indonesia jakarta.

Mangkunegara, 2003, Manajemen Sumber Daya Manusia Perusahaan /instansi /lembaga, PT. Remaja Rosdakarya, Bandung.

Nasution. 2001. Hukum Pertindungan Konsumen suatu Pengantar. Rineka Cipta. Jakarta

Prawirosentono, S. 1999. Kebijakan Kinerja Karyawan. BPFE UGM, Yogyakarta

Rivai, Veithzal dan Sagala, Ella Jauvani, (2005) Manajemen Sumber Daya Manusia untuk Perusahaan, Jakarta: PT. RajaGrafindo Persada.

Pebi Julianto. 2014. Evaluasi Pelaksanaan Program Satu milyar Satu kecamatan (Samisake) di kecamatan Depati Tujuh Kabupaten Kerinci Provinsi jambi tahun 2014. OSF Preprints. Jakarta.

Siagian . P. Sondang. 2009. Manajemen Sumber Daya Manusia. Bandung: Aksara baru Soekidjo Notoatmodjo. 2002. Pengembangan Sumber Daya Manusia. Jakarta: PT. Ranika Sugiyono, 2007, Metode Penelitian Administrasi, cetakan ke 15, Alfabeta Bandung The Liang Gie, 2002. Asas Asas Manajemen. Bandung : Mandar maja T, Hani Handoko. 2003. Manajemen. yogyakarta : BPFEE Zeithaml,dan Bitner, 2007, Delivering Ouality Service, Bumi Aksara, Jakarta Peraturan Presiden Nomor 86 Tahun 2007 Tentang Badan Pusat StatistikPeraturan Presiden Nomor 7 Tahun $\underline{2008}$ Tentang Organisasi dan Tata Kerja 